\title{
A Influência da Sazonalidade sobre a qualidade de água para microbacia do Urumari, Santarém/Pará
}

As águas superficiais urbanas ao receber uma determinada carga de poluentes alteram os parâmetros hidrológicos naturais e consequentemente a dispersão de contaminantes causa uma grande preocupação ambiental devido à disposição inadequada de compostos orgânicos e inorgânicos no corpo receptor que causam danos irreversíveis ao meio ambiente. Tendo em vista que as águas deste manancial são utilizadas como fonte de abastecimento para os moradores nas proximidades da microbacia são necessários estudos complementares de monitoramento sistemático na qualidade da água da microbacia, a fim de encontrar passivos ambientais de degradação em suas propriedades físico-químicas e bacteriológicas. O principal objetivo deste trabalho consistiu em avaliar o grau de comprometimento da microbacia Hidrográfica do Urumari em função da sazonalidade, e identificar a presença de compostos nocivos ao meio ambiente através do monitoramento do índice de qualidade de água, dos parâmetros físicos químicos e bacteriológicos presentes no corpo receptor. Para isso, foram analisados parâmetros físicos químicos e bacteriológicos em seis seções de coleta ao longo do leito da microbacia. Os parâmetros analisados na água, como $\mathrm{pH}$, turbidez sólidos totais dissolvidos, nitrito, nitrato, fosforo, ferro, zinco e coliformes termotolerantes. Mostraram-se fora dos padrões permitidos pela legislação, assim a água não está apropriada para nenhum tipo de uso ou atribuições estabelecidas pela legislação vigente. Já as análises de solo identificaram a presença de alguns metais, em diferentes proporções.

Palavras-chave: Qualidade de Água; Degradação Ambiental; Parâmetros Físico-Químicos.

\section{The Influence of Seasonality on the quality of water for the Urumari watershed, Santarém/Pará}

\begin{abstract}
As urban surface waters, to receive a load of pollutants altered by natural hydrological parameters and, consequently, a dispersion of contaminants, it causes great environmental concern due to an inadequate selection of compounds and inorganics in the receiving organism that causes irreversible damage to the environment. Bearing in mind that the waters from this financial point of view are used as a source of supply for residents in the microbasins, complementary studies of systematic monitoring of the watershed water quality, in order to find environmental degradation liabilities in their physical, chemical and bacteriological aspects. The main objective of this work is to evaluate the degree of impairment of the Urumari Watershed as a function of seasonality, and to identify the presence of harmfu compounds in the environment by monitoring the water quality index, clinical and bacteriological tests of medicines Of Quality. body receiver. For this, clinical and microbiological tests were analyzed in six collection tests over the time of the watershed. The parameters analyzed in water, such as $\mathrm{pH}$, turbidity, high dissolved, nitrite, nitrate, phosphorus, iron, zinc and thermotolerant coliforms. if it is displayed to the standards permitted by law, then water is not available for any type of use or assignments applied by current legislation. As a soil analysis, he identified the presence of some metals, in different proportions.
\end{abstract}

Keywords: Water Quality; Environmental Degradation; Physical-Chemical Parameters.

Topic: Engenharia de Recursos Hídricos

Reviewed anonymously in the process of blind peer.

Lucinewton Silva de Moura (iD)

Universidade Federal do Oeste do Pará, Brasil

http://lattes.cnpq.br/2577499231565227

http://orcid.org/0000-0002-9266-946X

lucinewton.moura@yahoo.com.br

Ruy Bessa Lopes (iD

Universidade Federal do Oeste do Pará, Brasil http://lattes.cnpq.br/4195469692527946

http://orcid.org/0000-0002-4806-8835

ruybessa@yahoo.com.br

Joseph Simões Ribeiro (iD

Universidade Federal do Oeste do Pará, Brasil

http://lattes.cnpq.br/1888011247908339

http://orcid.org/0000-0001-9715-816X

josephribeiro@hotmail.com
Received: 02/10/2020

Approved: 24/11/2020

\author{
Graciene do Socorro Taveira Fernandes (iD) \\ Universidade Federal do Oeste do Pará, Brasil \\ http://lattes.cnpq.br/9121021285937589 \\ http://orcid.org/0000-0002-2710-4251 \\ gracienefernandes@hotmail.com \\ Rodolfo Maduro Almeida \\ Universidade Federal do Oeste do Pará, Brasil \\ http://lattes.cnpq.br/1527651015984510 \\ http://orcid.org/0000-0003-4564-825X \\ rodolfomaduroalmeida@gmail.com \\ Sérgio Gouvêa de Melo (iD \\ Universidade Federal do Oeste do Pará, Brasil \\ http://lattes.cnpq.br/0148689717369496 \\ http://orcid.org/0000-0002-6946-6672 \\ sergiomeloccm@hotmail.com
}

\section{Referencing this:}

MOURA, L. S.; LOPES, R. B.; RIBEIRO, J. S.; FERNANDES, G. S. T.; ALMEIDA, R. M.; MELO, S. G.. A Influência da Sazonalidade sobre a qualidade de água para microbacia do Urumari, Santarém/Pará. Revista Ibero Americana de Ciências Ambientais, v.11, n.6, p.346357, 2020. DOI: http://doi.org/10.6008/CBPC2179-

6858.2020.006.0028 


\section{INTRODUÇÃO}

A água é primordial à vida na Terra e essencial para a humanidade (CECH, 2013). Entretanto, as múltiplas e complexas atividades desenvolvidas pelo homem intensificam e alteram o corpo hídrico gerando um mosaico de agravamento da qualidade ambiental das coleções de águas urbanas (TUNDISI et al., 2008). O crescimento exponencial de concentração da população urbana, e o crescente desenvolvimento tecnológico, contribuem para aumentar significativamente o número e a intensidade de passivos ambientais (TARGA et al., 2015).

A poluição ambiental sobre corpos hídricos urbanos pode levar a riscos à saúde pública (GANOULIS, 2009), entre seus diferentes agentes nocivos destacamos: contaminação microbiológica (patógenos), microalgas tóxicas cianofíceas, compostos químicos (inorgânicos e orgânicos), simplificação dos ambientes aquáticos (redução da biodiversidade), depleção de oxigênio (elemento essencial para a manutenção da estrutura e função dos ambientes aquáticos) e eutrofização.

No Brasil, a maior parte da população é urbana (SILVA et al., 2014; CARMO et al., 2014). Nesse contexto, à medida que a população se concentra nas cidades, tende a acelerar o processo de degradação desses corpos hídricos urbanos, uma vez que os efluentes domésticos e industriais são as principais fontes de destruição dos mananciais de água doce de acordo com Esteves et al. (2011). Desse modo, a urbanização desordenada e acelerada, pode tornar-se um fator potencial de vulnerabilidade hídrica e consequentemente a escassez de serviços de saneamento básico, são responsáveis por tais alterações (PEREIRA et al., 2010).

Além disso, a intervenção antropogênica nos ambientes lóticos, próximo de áreas urbanas pode ser um fator importante que afeta a biota do rio (MACHADO et al., 2015). Desse modo, as relações e interrelações inerentes às cidades criam diversidades de ações que, se não bem administradas, podem causar grandes transtornos às áreas urbanas (TUCCI, 2008) e a sustentabilidade do corpo hídrico (PORTUGAL JUNIOR et al., 2015).

Para Amazônia, segundo Homma (2005) cerca de 70\% da população da região Norte brasileira é urbana. Em Santarém, 90\% de seus habitantes vivem nas cidades. Segundo o mesmo autor, as concentrações populacionais localizadas ao longo do rio Amazonas estão transformando seu leito em um grande esgoto das cidades ao longo de sua calha (Manaus, Porto Velho, Parintins, Santarém, Macapá, dentre outras).

A região norte embora possua uma densidade populacional bem menor do que as demais regiões do Brasil, concentra sua população em poucas áreas metropolitanas especialmente próximas a zona ripária, tal painel sócio-político, constrói um cenário ambiental dramático quando os estados da região não possuem coleta e tratamento de esgoto em todos os seus municípios (LEONETI et al., 2011). Em paralelo a extração desenfreada dos recursos naturais da região amazônica, contribuíram efetivamente para ocupações populacionais, em locais onde havia água em abundância e de fácil acesso. Em decorrência da ocupação desenfreada e desordenada, houve alteração das características do meio ambiente, principalmente nas bacias hidrográficas e matas ciliares.

A cidade de Santarém, localizada no Oeste do Estado do Pará, é objeto deste estudo, tem possuí área 
bastante urbanizada e com infraestrutura precária (RODRIGUES et al., 2018). É uma cidade mononuclear de área central mais densa, enquanto as áreas periféricas apresentam urbanização de média à fraca (REZENDE et al., 2015). N o período de chuvas é marcado por muitos transtornos, prejudicando a mobilidade de veículos e pedestres, assim como interferindo negativamente nas atividades comerciais, institucionais e educacionais nas áreas afetadas.

A bacia do Urumari possui uma área de $27,04 \mathrm{~km}^{2}$. Pimentel et al. (2014), explicam que até o final da década de 1970, em virtude da localização das microbacias do Urumari, a leste e Irurá, a oeste, a expansão urbana de Santarém dava-se apenas no sentido sul da cidade e que a partir da década de 1980, a expansão avança e ultrapassa os igarapés que serviam de obstáculo. Oliveira (2008) também aborda o histórico de que, desde a década de 1980, Santarém passa por um processo de expansão urbana, que vem assumindo grandes proporções, ocasionando o espraiamento de sua periferia no sentido da Rodovia 163 (Cuiabá-Santarém) e Rodovia PA 370 (Santarém-Curuá-Una). Entretanto, mais de cinco décadas após o início da expansão, muito das áreas expandidas ainda continuam sem a devida inclusão dos serviços de infraestrutura básica e desenvolvimento urbano, acarretando problemas previsíveis, como alagamentos de ruas.

Sua vegetação encontra-se muito alterada no entorno de sua bacia, que vem sofrendo intensa degradação ambiental devido à acelerada expansão urbana, como relatam Pimentel et al. (2014): despejo de resíduos sólidos (lixo), lançamento de efluentes por galerias, assoreamento por construção de obras públicas, desmatamento e queimadas. O solo da bacia é predominante do tipo Argissolo Amarelo Distrófico típico A moderado com textura média argilosa de floresta equatorial subperenifólia, possuindo relevo ondulado a forte ondulado (SANTOS et al., 2002). Percebe-se também o tipo Latossolo Amarelo Distrófico típico A, com textura muito argilosa de floresta equatorial subperenifólia de relevo suave a ondulado segundo Santos et al. (2002). Com base nesses pressupostos, as questões que nortearam este estudo consistem em avaliar o grau de comprometimento da microbacia Hidrográfica do Urumari em função da sazonalidade, e identificar a presença de compostos nocivos ao meio ambiente através do monitoramento do índice de qualidade de água, dos parâmetros físicos químicos e bacteriológicos presentes no corpo receptor.

\section{Índice de Qualidade de Água - IQA}

O Índice de Qualidade de Água (IQA) e um parâmetro de fundamental importância para o monitoramento de qualidade da água que retrata através de um índice global em função de nove parâmetros considerados os mais representativos para a caracterização da qualidade de águas sendo eles: Coliforme fecais (termotolerantes), $p H, D B O$, Nitrato, fosforo total, temperatura da água, turbidez, sólidos totais dissolvido e oxigênio dissolvido. O IQA expressa o nível de contaminação de um manancial através de uma nota que varia de 0 a 100 que qualifica a água por faixa de cores como péssima, ruim, aceitável, boa e ótima conforme estabelecido na Tabela 1.

Tabela 1: Classificação da qualidade de água segundo IQA-CETESB.

\begin{tabular}{lll} 
Classificação & Cor & Faixa de IQA \\
\hline Ótima & Azul & $80 \leq I Q A \geq 100$ \\
Boa & Verde & $52 \leq I Q A \geq 80$
\end{tabular}




\begin{tabular}{lll} 
Aceitável & Amarela & $37 \leq 1 Q A \geq 52$ \\
Ruim & Vermelha & $20 \leq 1 Q A \geq 37$ \\
Péssima & Preta & $0 \leq I Q A \geq 20$ \\
\hline
\end{tabular}

\section{MATERIAIS E MÉTODOS}

\section{Área de estudo}

Para avaliar a dinâmica espacial, foi levado em consideração o possível risco de contaminação proveniente do uso inadequado e ocupação do solo, da escassez de saneamento básico e do lançamento de efluentes diretamente no corpo d'água (cargas pontuais de origem doméstica). Para tal, foram selecionadas seis seções de coleta, localizados mais próximo possível dos lançamentos dos efluentes.

A Figura 1 exibe a localização da microbacia hidrográfica do Urumari, destacando a sua inserção dentro do perímetro urbano do município de Santarém. Com área de cerca de $22,26 \mathrm{~km}^{2}$, a microbacia do Urumari alcança 15 bairros da cidade de Santarém. 0 mapeamento preliminar dos cursos d'água exibe um curso principal de comprimento aproximadamente $7,50 \mathrm{~km}$. Devido à dificuldade de acesso ao local, principalmente no período chuvoso o percurso total do curso d'água utilizado foi de 5,61 Km, considerando os pontos que foram possíveis ter acesso.

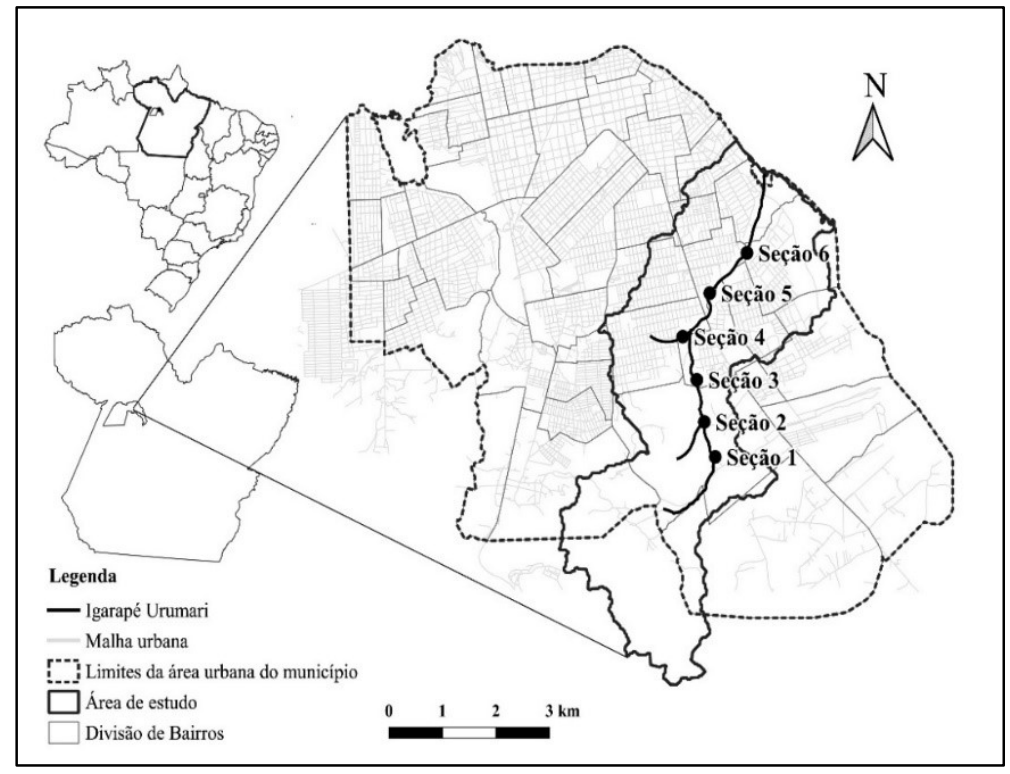

Figura 1: Localização da microbacia do Urumari.

Para a seleção dos locais de coleta na microbacia, levou-se em consideração os seguintes fatores: influência antrópica, distribuição equidistante dos pontos que abrangessem toda a extensão do corpo d'água e a facilidade de acesso a essas seções. A distância total entre a primeira e última seção de coleta foi de 5,61 Km, em um total de 6 divisões como observado na Tabela 2.

Tabela 2: Identificação das seções de amostragem realizadas na microbacia do Urumari.

\begin{tabular}{|c|c|c|c|c|}
\hline Seção de coleta & Distância (km) & Altimetria (m) & Latitude (S) & Longitude (W) \\
\hline Seção 1 & 0,00 & 54,50 & $02 \div 28 ' 46.5 " \mathrm{~S}$ & $54 \div 41^{\prime} 47.5^{\prime \prime W}$ \\
\hline Seção 2 & 1,39 & 37,88 & $02^{\circ} 28^{\prime} 38.06^{\prime \prime S}$ & $54^{\circ} 42^{\prime} 0.73^{\prime \prime} \mathrm{W}$ \\
\hline Seção 3 & 2,46 & 29,21 & $02^{\circ} 28^{\prime} 4.28^{\prime \prime S}$ & $54^{\circ} 41^{\prime} 59.73^{\prime \prime} \mathrm{W}$ \\
\hline Seção 4 & 3,13 & 26,79 & $02 \div 27^{\prime} 38.1$ "S & $54 \div 42^{\prime} 07.9^{\prime \prime} \mathrm{W}$ \\
\hline Seção 5 & 4,48 & 8,92 & $02^{\circ} 27^{\prime} 15.62^{\prime \prime S}$ & $54^{\circ} 41^{\prime} 51.17^{\prime \prime} \mathrm{W}$ \\
\hline Seção 6 & 5,61 & 44,20 & $02^{\circ} 26^{\prime} 52.25^{\prime \prime} \mathrm{S}$ & $54^{\circ} 41^{\prime} 28.54^{\prime \prime W}$ \\
\hline
\end{tabular}




\section{Análises dos parâmetros físico-químicos}

Os métodos de coletas e de análise da água foram baseados na NBR 9897, de junho 1987, que descreve o planejamento de amostras e efluentes líquidos e corpos receptores. In locu foi analisado o OD através de Oxímetro (55 YSI), com capacidade de medição de 0 a 20 mg/L e método Galvânico, Clark (níquel/chumbo). A vazão e velocidade foram determinadas através do equipamento FlowTracker, № de Série P-3260, fabricado pela Sontek/YSI.

As análises do oxigênio dissolvido se deram em dois períodos sazonais, chuvoso e não chuvoso. Os ensaios foram medidos em duplicata. As seções amostrais cobriram da nascente à montante da microbacia. As amostras de água foram coletadas a uma profundidade de cerca de $20 \mathrm{~cm}$ da superfície.

\section{Análises dos parâmetros bacteriológicos}

As análises dos coliformes se deram em dois períodos sazonais, chuvoso e não chuvoso. Os ensaios foram medidos em duplicata. As seções amostrais cobriram da nascente à montante da microbacia. Em cada campanha, as coletas foram feitas na parte superficial da água a, aproximadamente, $20 \mathrm{~cm}$ abaixo da lâmina d'água, quando foi possível, pois em algumas das estações de coleta o nível do leito da microbacia estava raso. $\mathrm{O}$ armazenamento e acondicionamento das amostras seguiram metodologia estabelecida pela CETESB (2018), bem como pelas exigências estipuladas pelos laboratórios responsáveis pelas análises: LaBac e Laboratório de Química Aplicada a Toxicologia saneamento Ambiental recursos Hídricos Para isso, cada laboratório enviou os seus recipientes devidamente etiquetados e preparados para o recebimento de suas respectivas amostras, as quais, posteriormente, foram depositadas em seus devidos frascos e volumes, acondicionadas em isopor e refrigeradas a $4^{\circ} \mathrm{C}$, até análise nos laboratórios, as quais aconteceram dentro dos prazos de validade, de acordo com os protocolos de amostragem e análise de corpos d'água, padronizada pelo Standard Methods for Water and Wastewater (APHA, 2012).

\section{RESULTADOS E DISCUSSÃO}

\section{Índice de Qualidade de Água - IQA}

O IQA é um índice de qualidade de água estabelecido pela agência do governo do estado de São Paulo CETESB (Companhia Ambiental do estado de São Paulo) que é responsável pelo controle, fiscalização, monitoramento e licenciamento de atividades geradoras de poluição no estado de São Paulo.

Na Tabela 3 estão apresentados os cálculos referentes as percentagens de saturação do oxigênio dissolvido e os índices de qualidade de água para a microbacia do Urumari analisados durante o período chuvoso. Podemos observar nesse período, que todos os pontos analisados apresentaram os valores compreendidos $52 \leq \operatorname{IQA} \geq 80$ (Tabela 1), que classifica a água como boa e de coloração verde.

A alta concentração de $O D$ de saturação na seção 1 (81,9 \%) pode ser justificado, em razão desta seção estar a montante da bacia de drenagem e, portanto, próximo aos afloramentos subterrâneos (POWER et al., 1999). A maior estabilidade da matéria orgânica no corpo d'água é verificada na seção 1 e decorre do 
baixo aporte alóctone de carga orgânica per capita (VON SPERLING, 2014) em função da menor ocupação antrópica na zona ripária do manancial (área de proteção permanente). Por outro lado, o estado eutrófico da bacia de drenagem, evidenciado pela cor verde no período chuvoso, e sua consequente atividade fotossintética possibilitou flutuações diárias de oxigênio no ambiente, condição está observada ao longo das seções de amostragem.

Nas seções 3 e 6 observamos um decréscimo na saturação de $O D$, provavelmente em função da maior densidade residencial ocupando a zona ripária e da consequente presença da poluição difusa através aumento do escorrimento superficial. Essa condição ambiental pode possibilitar o represamento de materiais e alterar a velocidade do curso d'água (BAYRAN et al., 2013) que por sua vez ocasiona um incrementa na temperatura da água, reduzindo a solubilidade do oxigênio (GONÇALVES et al., 2019), comprometendo uma maior respiração microbiana aeróbica.

Tabela 3: Cálculo da percentagem de saturação do oxigênio dissolvido e do Índice de Qualidade de Água (IQA) durante o período chuvoso na microbacia do Urumari.

\begin{tabular}{lllll}
\hline Seção de coleta & Percentagem de saturação OD (\%) & IQA/CETESB & Classificação da água & Cor \\
\hline Seção 1 & 81,9 & 72,3 & Boa & Verde \\
Seção 2 & 69,1 & 70,0 & Boa & Verde \\
Seção 3 & 58,8 & 62,8 & Boa & Verde \\
Seção 4 & 77,3 & 81,2 & Boa & Verde \\
Seção 5 & 64,8 & 55,4 & Boa & Verde \\
Seção 6 & 56,2 & 71,8 & Boa & Verde \\
\hline
\end{tabular}

Observamos que a seção 1 é única seção onde a água encontra-se em consonância com o índice IQA preconizado pela CETESB (classificado como água de boa qualidade e coloração verde), apresentando uma percentagem de saturação de oxigênio dissolvido de 70,7\% e IQA de 54,6 como pode ser visto na Tabela 4 . Na seção 2 a água é classificada como ruim de cor vermelha, e com uma concentração de oxigênio dissolvido em torno de 56,1 \%. No entanto nas seções 3, 4, 5 e 6 o IQA é classificado como aceitável de coloração amarela, e com valores médios de percentagem saturação de oxigênio dissolvido inferior a $60 \%$.

Tabela 4: Cálculo da percentagem de saturação do oxigênio dissolvido e do Índice de Qualidade de Água (IQA) durante o período não chuvoso da CETESB.

\begin{tabular}{lllll}
\hline Seção de coleta & Percentagem de saturação OD (\%) & IQA/CETESB & Classificação da água & Cor \\
\hline Seção 1 & 70,7 & 54,6 & Boa & Verde \\
Seção 2 & 56,1 & 36,0 & Ruim & Vermelha \\
Seção 3 & 57,1 & 43,8 & Aceitável & Amarela \\
Seção 4 & 57,0 & 48,2 & Aceitável & Amarela \\
Seção 5 & 58,6 & 43,7 & Aceitável & Amarela \\
Seção 6 & 59,5 & 41,3 & Aceitável & Amarela \\
\hline
\end{tabular}

\section{Análise dos parâmetros físico químicos período chuvoso}

Na Tabela 5 estão apresentados os parâmetros físicos químicos médios anuais durante o período chuvoso. A turbidez encontra-se em 51,21 UNT, está ligeiramente superior ao preconizado para a classe 1 (40 UNT) e dentro dos limites estabelecidos paras as classes 2 e $3 . \mathrm{O} \mathrm{pH} \mathrm{4,63} \mathrm{é} \mathrm{ácido} \mathrm{abaixo} \mathrm{do} \mathrm{nível}$ estabelecido pela resolução CONAMA N 357 , mais é uma característica das águas das microbacias da região de maneira geral apresentar aspectos ácidos. $O O D 4,84 \mathrm{mg} / \mathrm{L}$ está abaixo dos limites estabelecido para as classes 1 e 2 mais em consonância com a classe 3 . O ferro (Fe) 1,72 mg/L está dentro do limite estabelecido 
para a classe 3 mais 5,7 vezes superior aos limites de tolerância para as classes 2 e 3 . O zinco (Zn) está em consonância com o limite estabelecido para a classe 3, no entanto, 4,4 vezes superior aos limites de tolerância estabelecidos pela legislação para as classes 1 e 2 .

Tabela 5: Parâmetros fiscos Químicos médios anuais da microbacia do Urumari durante o período chuvoso.

\begin{tabular}{|c|c|c|c|c|c|}
\hline \multicolumn{6}{|l|}{ Período chuvoso } \\
\hline Parâmetros & Unidade & Classe 1 VMP & Classe 2 VMP & Classe 3 VMP & Resultado \\
\hline Turbidez & UNT & 40 & 100 & 100 & 51,21 \\
\hline Cor Aparente & $\mathrm{mg} \mathrm{Pt} / \mathrm{L}$ & Cor natural & 75 & 75 & Cor natural \\
\hline Temperatura da água & oc & $* *$ & $* *$ & $* *$ & 25,67 \\
\hline $\mathrm{pH}$ & $\mathrm{pH}$ & 6 a 9 & 6 a 9 & 6 a 9 & 5,43 \\
\hline Sólidos totais dissolvidos & $\mathrm{mg} / \mathrm{L}$ & 500 & 500 & 500 & 13,7 \\
\hline Amônia $\left(\mathrm{NH}_{3}\right)$ & $\mathrm{mg} / \mathrm{L}$ & 1,5 & 1,5 & 1,5 & 0 \\
\hline Nitrito $\left(\mathrm{NO}_{2}^{-}\right)$ & $\mathrm{mg} / \mathrm{L}$ & 1 & 1 & 1 & 0,01 \\
\hline Fósforo $(\mathrm{P})$ & $\mathrm{mg} / \mathrm{L}$ & 0,1 & 0,05 & 0,15 & 0,05 \\
\hline Fosfato $\left(\mathrm{PO}_{4}^{-}\right)$ & $\mathrm{mg} / \mathrm{L}$ & $* *$ & $* *$ & $* *$ & 0,01 \\
\hline DQO & $\mathrm{mg} / \mathrm{L}$ & $* *$ & $* *$ & $* *$ & 7,96 \\
\hline Nitrato $\left(\mathrm{NO}_{3}{ }^{-}\right)$ & $\mathrm{mg} / \mathrm{L}$ & 10 & 10 & 10 & 0 \\
\hline Ferro (Fe) & $\mathrm{mg} / \mathrm{L}$ & 0,3 & 0,3 & 5 & 1,72 \\
\hline $\mathrm{OD}\left(\mathrm{O}_{2}\right)$ & $\mathrm{mg} / \mathrm{L}$ & $>6,0$ & $>5,0$ & $>4,0$ & 4,84 \\
\hline Zinco (Zn) & $\mathrm{mg} / \mathrm{L}$ & 0,18 & 0,18 & 5 & 0,79 \\
\hline
\end{tabular}

VMP = Valor Máximo Permitido, ** = Valor não definido.

Na Tabela 6 estão apresentados os parâmetros físicos químicos médios anuais da microbacia do Urumari durante o período não chuvoso. Podemos observar com exceção do $O D$, da turbidez e do fosforo, todos os outros parâmetros estão dentro do permitido pela legislação vigente. A turbidez 191,63 UNT, é 4,8 vezes superior ao permitido para classe 1 e praticamente duas veze maior que o permitido para as classes 2 e 3. O pH está ácido abaixo do nível estabelecido pela resolução CONAMA N³57, mais é uma característica das águas das microbacias da região de maneira geral apresentar aspectos ácidos conforme informado anteriormente. $O O D 4,91 \mathrm{mg} / \mathrm{L}$ está abaixo do preconizado pela legislação para as classes 1 e 2 e em consonância para a classe 3.0 fosforo $0,23 \mathrm{mg} / \mathrm{L}$ está 2,3 vezes maior do que o recomendado pela legislação para a classe 3 e 4,6 e 1, 5 vezes maior que o recomendado para as classes 2 e 3 respectivamente.

Tabela 6: Parâmetros fiscos Químicos médios anuais da microbacia do Urumari durante o período não chuvoso.

\begin{tabular}{llllll}
\hline Período não chuvoso & \multicolumn{5}{l}{} \\
\hline Parâmetros & Unidade & Classe 1 VMP & Classe 2 VMP & Classe 3 VMP & Resultado \\
\hline Turbidez & UNT & 40 & 100 & 100 & 191,63 \\
Cor Aparente & $\mathrm{mg} \mathrm{Pt/L}$ & Cor natural & 75 & 75 & Cor natural \\
Temperatura da água & o. & $* *$ & $* *$ & $* *$ & 26,7 \\
pH & $\mathrm{pH}$ & 6 a 9 & 6 a 9 & 6 a 9 & 5,04 \\
Sólidos totais dissolvidos & $\mathrm{mg} / \mathrm{L}$ & 500 & 500 & 500 & 13,99 \\
Amônia $\left(\mathrm{NH}_{3}\right)$ & $\mathrm{mg} / \mathrm{L}$ & 1,5 & 1,5 & 1,5 & 0,02 \\
Nitrito $\left(\mathrm{NO}_{2}^{-}\right)$ & $\mathrm{mg} / \mathrm{L}$ & 1 & 1 & 1 & 0,02 \\
Fósforo $(\mathrm{P})$ & $\mathrm{mg} / \mathrm{L}$ & 0,1 & 0,05 & 0,15 & 0,23 \\
Fosfato $\left(\mathrm{PO}^{-}\right)$ & $\mathrm{mg} / \mathrm{L}$ & $* *$ & $* *$ & 0,6 \\
DQO & $\mathrm{mg} / \mathrm{L}$ & $* *$ & $* *$ & $* *$ & 11,43 \\
Nitrato $\left(\mathrm{NO}_{3}{ }^{-}\right)$ & $\mathrm{mg} / \mathrm{L}$ & 10 & 10 & 10 & 0,71 \\
Ferro $(\mathrm{Fe})$ & $\mathrm{mg} / \mathrm{L}$ & 0,3 & 0,3 & 5 & 0,12 \\
OD $\left(\mathrm{O}_{2}\right)$ & $\mathrm{mg} / \mathrm{L}$ & $>6,0$ & $>5,0$ & $>4,0$ & 4,91 \\
Zinco $(\mathrm{Zn})$ & $\mathrm{mg} / \mathrm{L}$ & 0,18 & 0,18 & 5 & 0 \\
\hline
\end{tabular}

VMP = Valor Máximo Permitido, ** = Valor não definido.

Na Figura 2a estão sendo apresentados os perfis da demanda química de oxigênio (DQO) ao longo do curso d'água durante o período chuvoso. Na Figura 2a, observa-se na segunda seção de coleta a existência 
de um ponto de menor concentração de DQO, o que pode ser justificado pela baixa carga de matéria orgânica presente nesta seção de coleta. A partir da segunda seção até a quarta seção de coleta há um crescimento exponencial da DQO, podendo ser justificado pela maior ocupação da área próximo ao local de coleta o que contribui efetivamente para uma maior deposição de matéria orgânica proveniente de diferentes fontes difusas.

$\mathrm{Na}$ Figura $2 \mathrm{~b}$ está apresentado o perfil da demanda química de oxigênio DQO ao longo do curso d'água da microbacia Urumari durante o período não chuvoso. Observa-se um crescimento linear entre a primeira e segunda seção de coleta, variando a concentração entre 5 a 11,5 mg/L. Em seguida sofre uma depleção até a terceira seção chegando a uma concentração de fosforo de $11 \mathrm{mg} / \mathrm{L}$ e posteriormente tem crescimento exponencial até a seção 5 onde alcança uma concentração máxima de $18 \mathrm{mg} / \mathrm{L}$ permanecendo praticamente inalterada até a seção 6 próximo a foz.

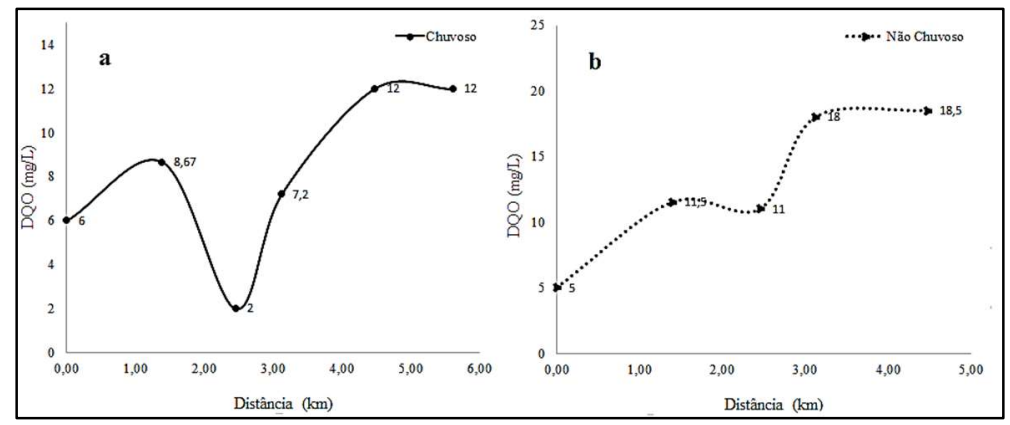

Figura 2: Perfil da demanda química de oxigênio - DQO ao longo do curso d'água da microbacia do Urumari em função da sazonalidade.

Na Figura 3a estão apresentados os perfis de concentração do nitrito ao longo do curso d'água em função da sazonalidade. Na Figura 3a, observa-se que entre a primeira e a segunda seção, há decaimento considerável da DQO até atingir um valor igual a zero que permanece inalterado até a terceira seção, voltando a crescer exponencialmente até a quarta seção de coleta e partir daí assumindo valores praticamente constante até a foz.

Na Figura 3b está apresentado o perfil de concentração do nitrito ao longo do curso d'água da microbacia do Urumari para o período não chuvoso. Observa-se que entre a primeira e a terceira seção ocorre um crescimento linear atingindo um valor máximo de concentração de 0,035 mg/L, sofrendo em seguida uma depleção expressiva até o ponto 6 alcançando uma concentração de 0,005 mg/L.

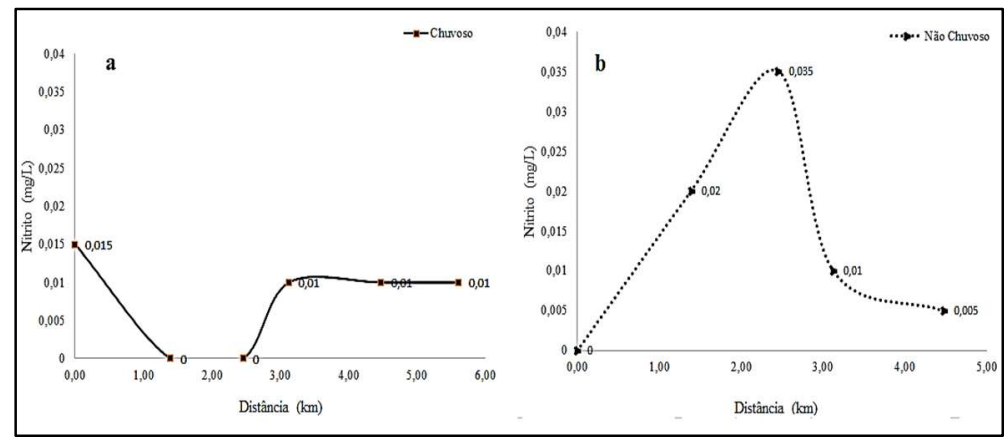

Figura 3: Perfil da concentração de nitrito ao longo do curso d'água da microbacia do Urumari em função da sazonalidade. 
$\mathrm{Na}$ Figura 4a observamos que o perfil de concentração do fosforo ao longo do curso d'água no período chuvoso assume valores mínimos iguais a zero entre a primeira e segunda seção. Cresce exponencialmente até alcançar um ponto máximo de concentração de $0,2 \mathrm{mg} / \mathrm{L}$ no intervalo entre a segunda e a terceira seção. Sofre uma depleção entre a terceira e quarta seção chegando a uma concentração de 0,05 $\mathrm{mg} / \mathrm{L}$ e permanecendo praticamente constante entre a quarta e quinta seção até chegar a uma concentração de zero na sexta seção próximo a foz.

$\mathrm{Na}$ Figura 4b observamos que o perfil de concentração do fosforo ao longo do curso d'água no período não chuvoso. Há um decaimento linear entre a seção 1 e 2 até alcançar um ponto de deflexão mínimo de concentração de fósforo de $0,15 \mathrm{mg} / \mathrm{L}$, seguido por um crescimento linear atingindo agora um ponto de máxima concentração de $0,4 \mathrm{mg} / \mathrm{L}$ na seção 3 . Aa partir da seção três ocorre um decaimento expressivo até alcançar as concentrações de zero nas seções 5 e 6 .

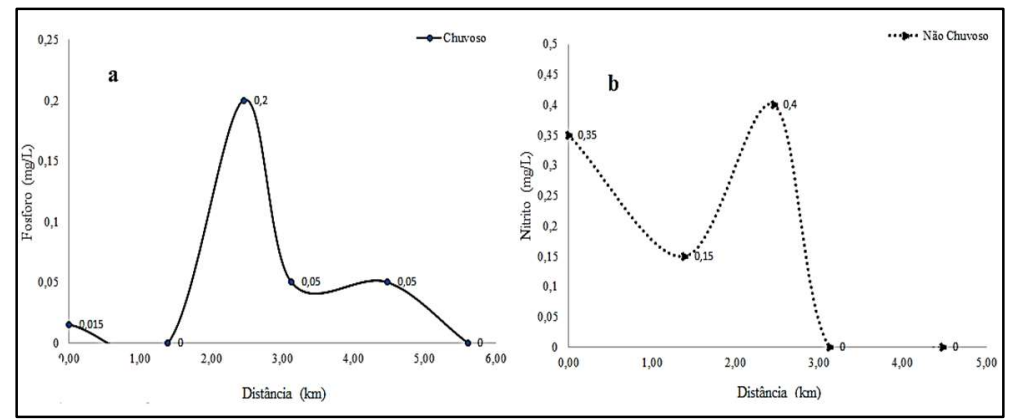

Figura 4: Perfil da concentração de fosforo ao longo do curso d'água da microbacia do Urumari em função da sazonalidade.

\section{Análise dos Parâmetros Bacteriológicos}

Na Tabela7 estão apresentados 0s resultados das análises de coliformes termotolerantes para as no período chuvoso e não chuvoso. De acordo com os resultados encontrados, no período não chuvoso, observa-se valor de NMP/100mL elevado na seção 6, ponto de desembocadura da microbacia do Urumari. Por outro lado, na campanha seguinte que aconteceu no período de chuvas, os níveis são iguais ou superiores a $2 \times 10^{2}$ de NMP $/ 100 \mathrm{~mL}$. Isso é explicado pelo acentuado volume de água das chuvas que ocorrem na região Amazônica. Aliado a este fator, está a carência de saneamento básico nos bairros por onde passa a microbacia do Urumari, e com isso matéria orgânica acaba sendo adicionada a água que escoa para o leito da microbacia.

Tabela 7: Parâmetros bacteriológicos em função da sazonalidade.

\begin{tabular}{lll}
\hline \multicolumn{2}{l}{ Coliformes termotolerantes (NMP/100mL) } & \\
\hline Seções de coleta & Período não chuvoso & Período chuvoso \\
\hline Seção 1 & 0 & 200 \\
Seção 2 & 0 & 700 \\
Seção 3 & 0 & 800 \\
Seção 4 & 0 & 400 \\
Seção 5 & 0 & 700 \\
Seção 6 & 810 & 800 \\
\hline
\end{tabular}

Em termos de quantidade de coliformes termotolerantes para os dois períodos fica evidente que o período de chuva é o que apresenta maior e constante a presença desse indicador microbiológico.

Espacialmente, no período de estiagem, o valor de $\mathrm{NM} / 100 \mathrm{~mL}$ se manteve igual em todas as seções 
de coleta exceto na seção 6 , onde o valor atingiu $8,1 \times 10^{2} \mathrm{NMP} / 100 \mathrm{~mL}$. Para o período de chuvas, com média de $6 \times 10^{2} \mathrm{NMP} / 100 \mathrm{~mL}$, com valor mínimo de 200 (seção 1) e máximo de 800 (seção 6).

Em todas as seções onde foram colhidas amostras da água da microbacia urbana, foi possível evidenciar pontos críticos em desfavor a manutenção da boa qualidade das águas da microbacia, podendo serem encontradas instalação de atividades econômicas como oficinas mecânica de automotores, empresas de processamento de produtos madeireiros, bares, banheiros e em toda a margem haviam residências instaladas as margens destas microbacia urbana. Devemos considerar que aliado a estes fatores está a carência de rede de esgoto e água para as famílias que vivem nos bairros pelos quais a microbacia do Urumari passa, nas quais grande parte destas residências possuem a descarga do esgoto sanitário lançado diretamente no leito do curso d'água.

Avaliar a presença e quantificar coliformes em águas é importante porque é de conhecimento que esses microrganismos podem impactar direta ou indiretamente a saúde humana. As bactérias coliformes podem causar doenças graves, como gastroenterite e diarreia, através da água poluída proveniente de esgoto, fossas sépticas, etc. Coliformes totais compreende todos os membros do grupo de bactérias coliformes, que inclui microrganismos de vegetação, solo e água. Os coliformes termotolerantes são os membros do grupo coliforme total que se originam no intestino intestinal de animais de sangue quente. Ambos os coliformes são importantes indicadores de qualidade da água nos rios porque eles podem determinar se a água está apropriada para fins recreacionais ou para consumo (SEO et al., 2019).

Em geral, os níveis de coliformes termotolerantes em águas superficiais geralmente atingem o pico após evento de chuva, e são mais elevados em áreas comerciais, residenciais, pastagens e terras agrícolas, mas menor em áreas florestais. Considerando esses fatores para o período de chuvas, abril de 2018, é evidenciado nas seções 1 e 4 onde há maior cobertura florestal e a mata ciliar ainda está razoavelmente preservada.

Segundo Hong et al. (2010) após análise de fatores que influenciam a ocorrência de coliformes (totais e termotolerantes) concluíram que a precipitação sazonal e o ambiente urbano circundante têm influência direta nos níveis destas bactérias, porém os coliformes termotolerantes sofrem interferência da urbanização.

\section{CONCLUSÕES}

Conclui-se nesse trabalho um considerado grau de comprometimento da qualidade do igarapé do Urumari onde foram identificados danos causados ao meio ambiente que vem sofrendo intervenções antrópicas, que contribuem efetivamente para a degradação dos recursos hídricos. A crescente demanda por água potável e o consequente crescimento desordenado e acelerado de moradias nas proximidades do leito do Igarapé do Irurá contribui para a deterioração desse manancial.

Por outro lado, a determinação das concentrações microbiológicas, presentes no meio, são imprescindíveis, pois a densidade bacteriana, em cursos d'água urbanos, são particularmente altas após as chuvas. Um outro aspecto relevante quando a contaminação microbiológica diz respeito a resistência bacteriana. As bactérias resistentes atravessam as plantas de tratamento de esgoto e conferem resistência 
as formas bacterianas indígenas ou nativas.

Esta pesquisa indicou que em termos bacteriológicos os pontos mais vulneráveis no trajeto do igarapé Urumari são o P6 (período chuvoso e não chuvoso) e P3 no período chuvoso. Desta forma se faz necessário monitoramento destes trechos da bacia urbana, no sentido de buscar melhorar a qualidade para que sejam mantidas as características do manancial.

\section{REFERÊNCIAS}

APHA. American Public Health Association. Standard Methods for the Examination of Water and Wastewater. 20 ed. Washington: APHA, 2012.

BAYRAN, A.; ONSOY, H.; BULUT, V. N.; AKINGI, G.. Influences of urban wastewaters on the stream water quality: a case study from Gumushane Province, Turkey. Environmental Monitoring and Assessment, New York, v.185, p.1285-1303. 2013. DOI: https://doi.org/10.1007/s10661-012-2632-y

CARMO, L. R.; DAGNINO, R. S.; JOHANSEN, I. C.. Transição demográfica e do consumo urbano de água no Brasil. Revista Brasileira de Estudos de População, Belo Horizonte, v.31, n.1, p.169-190, 2014. DOI: https://doi.org/10.1590/S0102-30982014000100010

CECH, T. V.. Recursos hídricos: história, desenvolvimento, política e gestão. Rio de Janeiro: LTC, 2013.

CETESB. Companhia de Tecnologia de Saneamento Ambiental. Relatório de qualidade das águas interiores do estado de São Paulo. São Paulo: CETESB, 2018.

ESTEVES, F. A.; MENEZES, C. F. S.. Papel da Água e da Limnologia na sociedade Moderna. In: ESTEVES, F. A.. Fundamentos de limnologia. 3 ed. Rio de Janeiro: Interciência, 2011. p.62-73.

GANOULIS, J.. Risk Analysis of Water Pollution. New Jersey: John Wiley \& Sons, 2009.

GONÇALVES, J. C. S. I.; ESPOSTO, M. S.. Water quality modelling of the São Joaquim stream, Brazil. Ciência e natura, Santa Maria, v.41, p.1-13, 2019. DOI: https://doi.org/10.5902/2179460X35540

HOMMA, A. K.. Amazônia: como aproveitar os benefícios da destruição?. Estudos Avançados, São Paulo, v.19, n.54, p.115-135, 2005. DOI: http://dx.doi.org/10.1590/S0103$\underline{40142005000200007}$

HONG, H.; QIU, J.; LIANG, Y.. Environmental factors influencing the distribution of total and fecal coliform bacteria in six water storage reservoirs in the Pearl River Delta Region, China. Journal of Environmental Sciences, Amsterdam, v.22, n.5, p.663-668, 2010. DOI: https://doi.org/10.1016/S1001-0742(09)60160-1

LEONETI, A. B.; PRADO, E. L.; OLIVEIRA, S. V. W. B.. Saneamento básico no Brasil: considerações sobre investimentos e sustentabilidade para o século XXI. Revista de Administração Pública, Rio de Janeiro, v.45, n.2, p.33148, 2011. DOI: https://doi.org/10.1590/S003476122011000200003
MACHADO, N. G.; NASSARDEN, D. C. S.; SANTOS, F.; BOAVENTURA, I. C. G.; PERRIER, G.; SOUZA, F. S. C.; BIUDES, M. S.. Chironomus larvae (Chironomidae: Diptera) as water quality indicators along an environmental gradient in a Neotropical urban stream. Revista Ambiente \& Água, Taubaté, v.10 n.2, p.298-309, 2015. DOI: http://dx.doi.org/10.4136/ambi-agua.1533

OLIVEIRA, J. M. G. C.. Expansão urbana e periferização de Santarém-PA, Brasil: questões para o planejamento urbano. In: COLÓQUIO INTERNACIONAL DE GEOCRÍTICA, 10. Anais. Barcelona: Universidade de Barcelona, 2008.

PEREIRA, S. F. P.; COSTA, A. C.; CARDOSO, E. S. C.; CORRÊA, M. S. S.; ALVES, D. T. V.; MIRANDA, R. G.; OLIVEIRA, G. R. F.. Condições de potabilidade da água consumida pela população de Abaetetuba-Pará. Revista de estudos ambientais, v.12, n.1, p.50-62, 2010.

PIMENTEL, D. R.; MELO, S.. Proteção ambiental no igarapé do Urumari, cidade de Santarém, Pará, Brasil. Revista EM FOCO-Fundação Esperança/IESPES, Santarém, v.1, n.22, 2014.

PORTUGAL JÚNIOR, P. S.; REYDON, B. P.; PORTUGAL, N. S. As águas minerais no Brasil: uma análise do mercado e da institucionalidade para uma gestão integrada e sustentável. Revista Ambiente \& Água, Taubaté, v.10, n.2, p.413-430, 2015. DOI: http://dx.doi.org/10.4136/ambi-agua.1357

POWER, G.; BROWN, R. S.; IMHOF, J. G.. Groundwater and fish: insights from northern North America. Hydrological Process, New Jersey, v.13, n.1, p.401-422, 1999. DOI: https://doi.org/10.1002/(SICI)10991085(19990228)13:3\%3C401::AID-HYP746\%3E3.0.CO;2-A

REZENDE, G. B. M.; ARAÚJO, S. M. S.. Análise da taxa de impermeabilização e tempo de concentração nas sub-bacias da área urbana de Barra do Garças - MT, Pontal do Araguaia - MT e Aragarças - GO. Revista Verde de Agroecologia e Desenvolvimento Sustentável, Pombal, v.10, n.5, p.27-37, 2015.

RODRIGUES, L. L.; BLANCO, C. J. C.. Vazão de pico em uma bacia hidrográfica com diferentes níveis de urbanização em Santarém/PA. Revista Ibero Americana de Ciências Ambientais, Aracajú, v.9, n.7, p.62-75, 2018. DOI: http://doi.org/10.6008/CBPC2179-6858.2018.007.0007

SANTOS, P. L.; OLIVEIRA JUNIOR, R. C.; RODRIGUES, T. E.. Mapa de reconhecimento dos solos do Planalto de Santarém, Estado do Pará. Escala 1:2000.000. Belém: EMBRAPA, 2002. 
SEO, M.; LEE, H.; KIM, Y.. Relationship between Coliform Bacteria and Water Quality Factors at Weir Stations in the Nakdong River, South Korea. Water, Basel, v.11, n.1171, 2019. DOI: http://doi:10.3390/w11061171

SILVA, D. F.; MOREJON, C. F. M.; LESS, F. R.. Prospecção do panorama do saneamento rural e urbano no Brasil. Revista Eletrônica do Mestrado em Educação Ambiental, Porto Alegre, p.245-257, 2014. DOI:

https://doi.org/10.14295/remea.v0i0.4449

TARGA, M. S.; BATISTA, G. T.. Benefits and legacy of the water crisis in Brazil. Revista Ambiente \& Água, Taubaté, v.10 n.2, p.234-239, 2015. DOI:

http://dx.doi.org/10.4136/ambi-agua.1629

TUCCI, C. E. M.. Águas urbanas. Estudos Avançados, São

Paulo, v.22, n.63, p.97-112, 2008. DOI:

https://doi.org/10.1590/S0103-40142008000200007

TUNDISI, J. G.; TUNDISI, T. M.. Limnologia. São Paulo: Oficina de Textos, 2008

VON SPERLING, M.. Estudos e modelagem da qualidade da água de rios. 2 ed. Belo Horizonte: Universidade Federal de Minas Gerais, 2014

A CBPC - Companhia Brasileira de Produção Científica (CNPJ: 11.221.422/0001-03) detém os direitos materiais desta publicação. Os direitos referem-se à publicação do trabalho em qualquer parte do mundo, incluindo os direitos às renovações, expansões e disseminações da contribuição, bem como outros direitos subsidiários. Todos os trabalhos publicados eletronicamente poderão posteriormente ser publicados em coletâneas impressas sob coordenação da Sustenere Publishing, da Companhia Brasileira de Produção Científica e seus parceiros autorizados. Os (as) autores (as) preservam os direitos autorais, mas não têm permissão para a publicação da contribuição em outro meio, impresso ou digital, em português ou em tradução. 